\author{
Beata K. Obsulewicz \\ (Katolicki Uniwersytet Lubelski)
}

\title{
Nalepki na walizce i błoto. O motywach ulicy w Henryku Flisie Stanisława Antoniego Muellera
}

\section{Między Rokomyszem i Drohobyczem}

Literacki Drohobycz nie jest miastem Stanisława Antoniego Muellera. Drohobycz jest miastem Brunona Schulza ${ }^{1}$, Andrzeja Chciuka ${ }^{2}$ i Henryka Grynberga ${ }^{3}$. Historia literatury wyznaczyła swoją hierarchię, precyzyjnie wskazała drohobyckie legendarne miejsca oraz tematy i nie ma potrzeby, by jej werdykty poddawać rewizji. Za brakiem konieczności dokonywania korektur przemawia przede wszystkim... postawa Stanisława Antoniego Muellera ${ }^{4}$. Po pierwsze nigdy nie zabiegał o rozgłos swej rozgrywającej się

1 B. Schulz, Sklepy cynamonowe, Warszawa 1934; tenże, Sanatorium pod klepsydra, Warszawa 1937. Zob. też: S. Wróbel, Mity, xięga, lektury. Galaktyka Brunona Schulza, [w:] tenże, Galaktyki, biblioteki, popioły, Kraków 2001, s. 252-264; B. Małaczyński, A może naprawdę nie było już miasta..., [w:] Miasto. Przestrzeń, topos, człowiek, red. A. Gleń, J. Gutorow, I. Jokiel, Opole 2005, s. 167-176; Willa Bianki. Mały przewodnik drohobycki dla przyjaciót (fragmenty), oprac. P. Próchniak, Lublin 2006.

2 A. Chciuk, Atlantyda. Pierwsza opowieść o księstwie Bałaku, Warszawa 1989; tenże, Ziemia księżycowa, Warszawa 1989. Zob. też A. Czajkowska, Kraj lat dziecinnych, ten zawsze zostanie. Wspótczesne realizacje romantycznego toposu powrotu w twórczości Andrzeja Chciuka i Tadeusza Konwickiego, [w:] Stare i nowe w literaturze najnowszej, red. L. Wiśniewska, Bydgoszcz 1996; B. Żongołłowicz, Andrzej Chciuk. Pisarz z antypodów, Kraków 1999; Z. Wasilewska-Lipke, Drohobycka Atlantyda Andrzeja Chciuka, [w:] Drohobycz wielokulturowy, red. M. Dąbrowski, W. Meniok, Warszawa 2005, s. 105-120.

3 H. Grynberg, Drohobycz, Drohobycz, Warszawa 1997. Zob. P. Marton, Opowiadanie „Drohobycz, Drohobycz" Henryka Grynberga. Rzeczywistość alegorii, [w:] Drohobycz wielokulturowy, s. 121-136.

${ }^{4}$ O biografii i twórczości S.A. Muellera zob. M. Puchalska, Stanisław Antoni Mueller, [hasło w:] Obraz literatury polskiej XIX i XX wieku, seria V: Literatura okresu Młodej Polski, t. III, Kraków 1973, s. 417-431; Mueller Stanisław Antoni (1877-1944), [hasło w:] Bibliografia literatury polskiej Nowy Korbut, t. XVI, Warszawa 1982, s. 457-458; M. Puchalska, Mueller Stanistaw Antoni, [hasło w:] Polski stownik biograficzny, t. XXII, Wrocław 1977, s. 254-256. 
w Drohobyczu pierwszej (i zresztą ostatniej) powieści Henryk Flis ${ }^{5}$, mimo życzliwego jej przyjęcia przez krytykę ${ }^{6}$. Po drugie nie był przez urodzenie, dzieciństwo, młodość lub śmierć związany z Drohobyczem. Pojawił się tam jako rodowity lwowianin najpierw w czasie studiów, gdyż tam zamieszkała jego matka z drugim mężem ${ }^{7}$, potem w związku z karierą zawodowa dokładniej: by objąć koncypienturę adwokacką ${ }^{8}$ Trwała ona trzy lata (1903-1906). Z tym miastem związany był do roku $1910^{9}$, chociaż pracował też we Lwowie w Namiestnictwie i Sądzie Krajowym. Reszta jego życia upłynęła w innych przestrzeniach (stolica Galicji, potem Kraków i Warszawa). Drohobycz był dla pisarza ważnym (z powodów autobiograficznych ${ }^{10}$ ), choć tymczasowym przystankiem. Okoliczności powyższe nie przekreślają wszakże faktu, że dzięki Muellerowi Drohobycz został wprowadzony do rejestru młodopolskich miast literackich a Henryk Flis daje pierwszy w literaturze polskiej obraz tego niezwykłego miejsca ${ }^{11}$.

5 S.A. Mueller, Henryk Flis. Powieść, t. I-II, Lwów 1908 (pierwsze wydanie nakładem lwowskiej Księgarni Polskiej B. Połonieckiego); wyd. 2 - S.A. Mueller, Henryk Flis. Powieść, t. I-II, oprac. M. Puchalska, Kraków 1976. W niniejszym szkicu korzystam z wydania 2. Cytaty z niego lokalizuję w nawiasach następująco: HF (Henryk Flis), cyfra rzymska - numer tomu, cyfra arabska - numer strony.

6 Z ważniejszych pozycji wymienić należy: T. Dąbrowski, Wizerunki, „Krytyka” 1908, t. 2, s. 47-50; J. Flach, S. A. Mueller. "Henryk Flis”, „Przegląd Polski” 1908, t. 170, s. 356-358; W. Gomulicki, „Kraj” 1908, nr 184; W. Gostomski, S.A. Mueller. "Henryk Flis. Powieśćc, „Przegląd Powszechny” 1908, t. 99, s. 252-253; K. Irzykowski, Jeszcze jeden Hamlet, [w:] tenże, Czyn i słowo. Głosy sceptyka, Lwów 1913, s. 283-292; W. Jabłonowski, Wyższy człowiek, "Słowo Polskie” 1908, nr 359, s. 1. M. Puchalska zaznacza jednak, że „debiut Muellera, chociaż wywarł wrażenie na kilku nowatorach (Ortwin, Lack, Irzykowski, Stefan Gacki, Tadeusz Dąbrowski), nie przebił się wtedy poza kręgi krytyki ściśle fachowej". M. Puchalska, Rokomysz - świat. (O perspektywach poznawczych $i$ artystycznych utworu Stanisława Antoniego Muellera), [posłowie do:] S.A. Mueller, Henryk Flis. Powieść, t. I-II, Lwów 1908, s. 270.

7 M. Puchalska, Mueller Stanisław Antoni, [hasło w:] Polski słownik biograficzny, s. 255.

8 M. Rydlowa, Nota wydania, [w:] S.A. Mueller, Henryk Flis, t. II, s. 318. Maria Rydlowa wskazuje datę 1899 jako rok zamieszkania Muellera w Drohobyczu. M. Puchalska podaje datę 1903 i to do jej opinii wypada się przychylić. Mueller w latach 1897-1903 studiował prawo i przedmioty humanistyczne (uczestniczył w seminariach z historii filozofii, historii sztuki i historii literatury niemieckiej) we Lwowie na Uniwersytecie Jana Kazimierza, w 1902 roku uzyskał tytuł doktora prawa. Do tego czasu w Drohobyczu jedynie bywat.

9 Wówczas przeniósł się na stałe do Lwowa i tam otworzył kancelarię adwokacką.

10 „Oto Stanisław A. Mueller! Tak, to nie jest znany adwokat, ale jedynie i wyłącznie hiperkulturalny autor Henryka Flisa, co więcej, to sam Flis, który przywdział na twarz zbyt widocznie przesadną maskę ironii, szyderstwa i nonszalancji, aby zakryć nią płaczącą brzozę sentymentu, która w duszy jego rozwiała delikatne gałązki, drżące za najlżejszym podmuchem życiowych wiatrów" - W. Kozicki, Gaj Akademosa, Lwów 1912, s. 290.

${ }^{11}$ Niniejszym przychylić się należy do zdania T. Dąbrowskiego, że "sprawom naftowym wyłącznie poświęcali uwagę dotychczasowi eksploratorowie powieściopisarscy 
Niniejszy szkic to zaledwie prolegomena do pełnego odczytania sposobów prezentowania ulic ${ }^{12}$, zaułków i zabłoconego bruku Rokomysza. Odbiorcy ${ }^{13}$ i edytorzy ${ }^{14}$ Henryka Flisa nigdy nie mieli problemu z ukazaniem jego podobieństwa do Drohobycza u schyłku XIX i na początku XX wieku.

\section{Nalepki na walizce}

Gdy umęczony kolejową podróżą Henryk Flis dotarł do hotelu Pod Czarną Gwiazdą w Rokomyszu, nie marzył o niczym innym, jak tylko o chwili wytchnienia.

Drohobycza: Rogosz, Sewer czy Gruszecki" (tenże, dz. cyt., s. 46). Miasto jako przestrzeń życia mieszczan zostało wskazane, lecz nie w pełni rozpoznane w tekstach: J. Rogosza W piekle galicyjskim. Obraz z życia, Gródek 1896; I. Sewera-Maciejowskiego Nafta, t. 1-3, Warszawa 1894; tenże, Ponad sity, t. 1-2, Warszawa 1900; czy T. Gruszeckiego Dla miliona, Warszawa 1900.

${ }^{12}$ Termin „ulica” jest trudno definiowalny. W niniejszym szkicu przyjęto założenie, że jest to „miejska droga, obustronnie obudowana”. Ulice przedmiejskie, podmiejskie, zamiejskie będą zatem miejskimi drogami w trakcie zabudowywania. Ulica jest podstawowym elementem struktury miasta, warunkiem sine qua non uznania przestrzeni zabudowanej za miejską. Jakość ulicy jako formy przestrzennej zależy od jej obrazowości (zob. K. Lynch, L'image de la cité, Paris 1976), czyli od zdolności generowania w świadomości postrzegających ją jednostek łatwych do zapamiętania i zidentyfikowania obrazów. Czynnikami generującymi obrazowość ulicy są: szerokość, wygląd fasad budynków, umiejscowienie w układzie innych ulic, ukierunkowanie, społeczny charakter ulicy (jej mieszkańcy), rodzaj aktywności prowadzonej przy ulicy itd. Forma przestrzenna i społeczna ulicy nadają jej niekiedy charakter znaku, który jest na ogół rozpoznawalny przez przechodnia. Ustalenia na podstawie: Ulice, [w:] B. Jałowiecki, M.S. Szczepański, Miasto i przestrzeń w perspektywie socjologicznej, wyd. II zmien., Warszawa 2006, s. 395-404.

${ }^{13}$ Zob. T. Dąbrowski pisał: „Drohobycz - nie żaden Rokomysz, co tu dłużej ukrywać!” (tenże, dz. cyt., s. 46). M. Popiel, Oblicza wzniostości. Estetyka powieści młodopolskiej, Kraków 2003, s. 165; M. Sołtysik, Klimat stolicy galicyjskiej nafty. Dowódcy, artyści, adwokaci czyli fenomen Drohobycza, „Palestra” 2009, nr 3-4 (http://www.palestra.pl/index.php?go=artykul\&id=3008; dostęp dn. 04.04.2013); J. Wolski, „Krew ziemna” Stanistawa Vincenza - mitologia ropy naftowej, „Kyjiwski Polonistytzni Studiji”, t. XIX, Kiev 2012, s. 69.

${ }^{14}$ Zob. M. Puchalska, Rokomysz-śzwiat..., s. 286: „Powieść Muellera daje wnikliwy, a miejscami porywający obraz Drohobycza jako stolicy galicyjskiej nafty. Ukazany on został w swej autentycznej substancji urbanistycznej [...]. Trzy nałożone na siebie skale czasoprzestrzenne, jedna - utwierdzona głęboko w historii, wspaniała, druga - ledwie wczorajsza, nędzarska, trzecia - nakierowana ku przyszłości, niepokojąca, przenikają też świat ludzkich wyobrażeń, namiętności, machinacji [...]". Oprócz tego w objaśnieniach i komentarzach rzeczowych do tekstu powieści znajdują się liczne wzmianki lokalizujące punkty topografii Rokomysza na mapie ówczesnego Drohobycza. 
Lecz nagle spostrzegłszy, że służący hotelowy zabrał jego tobołki z wozu i zaczął wchodzić na schody, pobiegł za nim pospiesznie i wydarł mu popędliwie z rąk walizkę, z widoczną trudnością tłumiąc gniew. Opatrzył ją starannie, przykleił śliną naddarty przez nieuwagę sługusa anons zagranicznego hotelu i wniósł ją sam z przesadną ostrożnością do wskazanego pokoju. Potem zamknął drzwi na dwa spusty. (HF I, 11)

Na przypuszczenie zaciekawionego właściciela hotelu, że muszą się w niej mieścić „niezwykle delikatne rzeczy, skoro pan dobrodziej tak [jej - B.K.O.] strzeże... jak oka w głowie....”(HF I, 12), odparł: „W walizce nie ma nic nadzwyczajnego. I nie o jej zawartość mi chodziło, ale raczej, że się tak wyrażę... o walizkę samą..." (HF I, 12).

- Ach... rozumiem... rozumiem... Z pewnością drogi sercu podarek lub pamiątka rodzinna... Co? nie zgadłem?...

Flis żachnął się zniecierpliwiony:

- Niechże pan już raz u licha zapomni o tej głupiej sprawie..

- Przepraszam... stokrotnie przepraszam za natrętność... tylko, że mi to tak od razu w oko wpadło [...]. (HF I, 12-13)

Dlaczego nieodzowne jest rozpoczęcie analizy motywu ulicy w prozie powieściowej Stanisława Antoniego Muellera od tego cytatu? Przywieziona do Rokomysza walizka „wpada w oko”, gdyż jest strzeżona ,jak oko w głowie". Flis wyznaje prawdę, gdy informuje rozmówcę, że walizka nie kryje wewnątrz żadnego skarbu. Rzeczony przedmiot nie jest bowiem żadnym relikwiarzem, ale transparentem. Jego zewnętrzność, manifestacyjna naoczność, jest dużo ważniejsza niż mizerne wnętrze. Ukazuje to dobrze gest przyklejania naddartej hotelowej nalepki własną śliną oraz nadmiar emocji, które Flis wkłada w staranie o to, by nie narazić jej na jakiekolwiek niebezpieczeństwo zniszczenia. Tak chroni się tylko najcenniejsze certyfikaty.

Trzeba zatem przywołać długi, lecz konieczny w dalszych etapach wywodu passus, w którym z hermeneutyczną pieczołowitością objaśniona zostaje przyczyna troski o stan nalepek:

Ziewnął przeciągle, rozprostował zziębłe członki i rzucił się na łóżko, otulając w ciepłą derkę. Wzrok jego padł na anonse, okrywające walizkę: Schweizerhof-München... Sans-Souci-Nürnberg... Barbarossa-Konstanz... Venezia - Albergo Orientale a Capello Nero... Ożywił się, przymknął oczy.

Ach! Tam, gdzie cytryna dojrzewa,

Pomarańcz blask ${ }^{15} \ldots$

Przejmujący dreszcz nim trząsł, łaskotliwy dreszcz, co od stóp się poczyna, przewierca nogi, krzyże, aż wreszcie mrówczym ścierpem obejmuje mózg. Dreszcz melodramatycznego

\footnotetext{
${ }^{15}$ Fragment pieśni Mignon Znaszli ten kraj z Wilhelma Meistra J.W. Goethego w przekładzie
} A. Mickiewicza; HF I, 253. 
roztkliwienia. Łzy napływają do oczu, a serce się ściska... Flis odwrócił się do ściany i otulił się cieplej w kołdrę. Był straszliwie znużony. I smutny. Jaki smutny... Wenecja... Monachium... Norymberga... Sans-Souci... Gdzie słońca blask...

Ach! słońce!... Jakież inne, dostojne i powściągliwe tam ono! Z jak kornym zaparciem swej szczodrej rozrzutności budzi czułymi dotknięciami nieśmiertelne życie w liniach, kształtach, barwach! Jakby zagasić pragnęło i przytłumić swój żar, zeskromnieć i na plan daleki się osunąć wobec cudów przez wieki geniuszem ludzkim wypracowanych, w które ono jedynie przecież tchnąć zdolne rozśpiewane tętno życia. Nabożne uszanowanie czyni tam krok cichym i lekkim. Zda się, że stopa nad ziemią się unosi, byle tylko nie wtrącić najlżejszego szmeru w zachwycony spokój. Na barki się osuwa słodkie rozkoszne brzemię oddalonych wieków, zmartwychwstałych nagle z piwnic zakurzonych foliałów w bajeczną rzeczywistość, dającą się ująć i sprawdzić. Namaszczone spojrzenie spotyka się na wyszczerbionych, poczerniałych murach z poważnym, zadumanym wzrokiem zgasłych przed wiekami pokoleń, a poczucie ciągłości nieprzerwanej wysiłków geniusza ludzkiego napełnia duszę krzepką otuchą, męską wiarą we wzniosłe cele ludzkości. W rozjęczonej $\mathrm{w}$ takt dzwonów porannych piersi budzi się poczucie niepokojącej swym ogromem, odurzającej blaskiem, rwącej do heroicznych prób i lotów, dostojnej godności istoty, której czoło opromienione jasną aureolą wszelkiej sławy minionej i dumną świadomością wspólnictwa w ogólnoludzkiej kulturze. I marzenia porywają duszę w swe naiwne kołyski, rozchybotane tętnem miarowych przypływów i odpływów uczucia [...]. Oto zza mgieł i dymów wyłania się Norymberga, owo małe, prastare miasto w wielkim nowym mieście [...]. Drezno i Monachium [...]. [...] koronkowy cud Wenecji [...]. (HF I, 17-19)

Fascynacja wielowiekową cywilizacją Europy, poczucie przynależności do niej, "melodramatyczny [sic!] dreszcz” towarzyszący rozmyślaniu nad melanżem historii (przeszłości), sztuki oraz natury (klimat), euforia wynikająca z poczucia włączenia w świat kultury budowanej przez pokolenia każą interpretować etykiety na walizce w kategoriach najwyższych ocen na świadectwie poświadczającym dojrzałość świadomego swej tożsamości i aspiracji Europejczyka. Trywialne papierowe pamiątki z odwiedzanych hoteli są markami na certyfikacie potwierdzającym prawidłowo wykorzystaną podróż edukacyjno-inicjacyjną, jaką w XIX wieku dla rzesz młodych ludzi stanowiła grand tour ${ }^{16}$. Dzięki tej peregrynacji funkcję miast idealnych dla "kandydata praw” spełniać będą miasta Włoch ${ }^{17}$ i miasta niemieckie związane z ośrodkami sztuki.

${ }^{16} \mathrm{O}$ grand tour zob. M. McCarthy, Art Education and the Grand Tour, [w:] Art, the Ape of Nature. Studies in Honor of H.W. Janson, ed. M. Barasch, L. Freeman Sandler, New York 1981, s. 477-494; wypowiedź O. Płaszczewskiej (http://www.dekadaliteracka.pl/?id=237; dostęp dn. 04.04.2013).

${ }^{17}$ M. Puchalska zauważa: „[Flisowi - B.K.O.] cennych doznań dostarcza włoski szlak podróży artystycznych. To stamtąd spływa na udręczonego człowieka współczesnego łaska afirmacji rzeczywistości, harmonijnego zespolenia się ze światem, a więc postawy warunkującej twórczość o wyrazie klasycznym" (taż, Rokomysz-świat, s. 274). W upodobaniu kultury włoskiej widzi Puchalska ślad przynależności Muellera do kręgu „płanetników”, skupionego wokół M. Wolskiej. Przyznając generalnie rację autorce posłowia do Henryka Flisa, zauważyć wszakże należy, że nie tylko Włochy (południe Europy) są dla bohatera 
Miasta owe, za którymi Flis będzie tęsknił i podobieństw do których będzie wkoło siebie szukał, zaprojektowały jego styl odbioru przestrzeni miejskiej. Stały się estetycznymi wzornikami, matrycami probierczymi. Zauważyć należy, że nie są to miasta, którym w XIX wieku dane było doświadczyć radykalnej modernizacji, bądź wywołanej koniunkturą przemysłową (np. Manchester, Turyn), bądź wymuszonej przez sytuację komunikacyjno-higieniczną kształtującej się metropolii (Londyn, Paryż po przebudowie pod kierunkiem Haussmanna) ${ }^{18}$. Trzy "klasycyzujące” komponenty: światło, skojarzenia z uznanymi dziełami sztuki i ślady celowej myśli urbanistycznej będą musiały spotkać się i dopełnić, by w aksjologicznym modelu Flisa zakątek miasta mógł zostać zaaprobowany, zidentyfikowany jako przestrzeń stymulująca do twórczej egzystencji. To zadanie jawi się jako niezwykle trudne, gdyż Rokomysz, ostatni przystanek na trasie jego grand tour, to miasto prowincjonalne, o charakterze nieprzejrzystym (przemieszane ślady stosunkowo długiej miejskiej tradycji i ingerencja czynników związanych z uprzemysławianiem wywołanym odkryciem złóż naftowych w okolicy), w dodatku poznawane $w$ okresie jesienno-zimowo-przedwiosennym. Niewiele miast środkowoeuropejskich $\mathrm{w}$ takiej porze potrafi zamaskować swe architektoniczno-topograficzne defekty. Nie dziwi zatem brak na walizce Flisa nalepki „Pod Czarną Gwiazdą - Rokomysz”, gdy podjął decyzję o opuszczeniu placówki koncypienckiej. Prymitywny hotel pewnie takiej wizytówki nie posiadał. Gdyby nawet ją miał, nie pasowałaby do wypieszczonej, chronionej walizkowej kolekcji lub wpisywała się w nią jako element dysonansowy. Kłuła w oczy.

\footnotetext{
ideałem kultury, ale także obszar dzisiejszych Niemiec, czyli jej zachód (pomijamy tu kwestie absorbujące współczesnych historyków kultury, gdzie kończą się granice owego zachodu, a zaczyna się obszar środkowoeuropejski, a następnie wschodnioeuropejski). Co ciekawe, wcale nie są nim najbliższe geokulturowo Austro-Węgry. O istotnie ważnej dla młodopolan topice oscylującej wokół podróży do Włoch zob. E. Łoch, Przestrzenie włoskie w podróżopisarstwie polskim w drugiej połowie XIX wieku, [w:] taż, Wokót modernizmu. Studia o literaturze XIX i XX wieku, Lublin 1996, s. 163-212; F. Ziejka, Młodopolscy Europejczycy, [w:] Stulecie Młodej Polski, red. M. Podraza-Kwiatkowska, Kraków 1995, s. 220-227; W. Sołtys, „Niech będzie wiekowi naszemu, jak pożąda...". Fascynacje źródłami kultury i moda na periegetyczny szkic z historii włoskiego renesansu w pierwszej dekadzie XX wieku, [w:] Modernistyczny wizerunek człowieka, red. J. Szcześniak, D. Trześniowski, Lublin 2001, s. 63-80; artykuły zebrane w poświęconym podróżom do Włoch numerze „Prac Filologicznych” 2009, t. LVII.

${ }^{18} \mathrm{O}$ zjawisku modernizacji miast w tym czasie zob. D. Kudelska, Kadry miasta i retoryka jego opisu w malarstwie polskim (ok. 1860-1900), [w:] Polis - urbs - metropolis. Materiaty LIX Ogólnopolskiej Sesji Naukowej SHS, red. L. Lameński, E. Błotnicka-Mazur, Warszawa 2011, s. 203-204. W szerszej perspektywie: E. Rybicka, Modernizowanie miasta. Zarys problematyki urbanistycznej w nowoczesnej literaturze polskiej, Kraków 2003.
} 


\section{Gościniec}

Cechą charakterystyczną literackiego Rokomysza jest dworzec kolejowy położony na peryferiach miasta ${ }^{19}$. Pierwsze spotkanie $\mathrm{z}$ drogą $\mathrm{w}$ tym mieście nie pozostawia złudzeń co do poziomu cywilizacyjnego rokomyskiej civitas. I znów należy posłużyć się dłuższym cytatem, by ukazać strategie opisu i sposoby doświadczania ulicznej przestrzeni:

Drynda powlokła się skrzypiąc, stukając o kamienie, trzęsąc niemiłosiernie po wybojach gościńca, ciskając spod kół całe fontanny gęstego, lepkiego błota koloru czekolady. [...] A drynda wlokła się bez końca, mijając niskie, moknące w błocie i dżdżu chałupy przedmiejskie, niechlujne, o małych, krzywych szybkach, zarytych w zamokłe przyzby, ziejących wonią zastałego dymu kurnego, stęchlizny i wilgoci. Po stratowanych grządkach warzywnych ogrodów, po wstrętnych śmieciskach, po gnojówkach wezbranych wodą deszczową i przelewających się przez brzegi ku wpadniętym w ziemię progom, wałęsały się ospale i ciężko żerujące wrony i kruki [...]. Rzadkie, pękate wierzby przydrożne, o bezmyślnej fizjonomii wodogłowów, chybotały bezsilnie piszczelami szeleszczącymi sucho. Te długie, obnażone rzędy wierzb po obu stronach gościńca nadawały całej okolicy charakter beznadziejnej melancholii, ciągnęły się w dal, jak okiem sięgnąć, niby szeregi nagich starczych ciał, borykających się daremnie w konwulsyjnych podrzutach i szamotaniach z rozmokłym bagniskiem, co usidliło ich nogi i z wolna lecz niezawodnie ciągnęło je w głąb w swe miękkie, śmiertelne spowicia... Drynda minęła parę nowych kamienic, zionących z otwartych na oścież okien wilgotnym, nudnym zawiewem nie osuszonych murów, widocznie już zamieszkanych, choć nie zdołano jeszcze usunąć rusztowań i dokończyć wyprawy [...]. Koń, powściągnięty nagłym szarpnięciem lejców, zaparł się o bruk, ale tak był wyczerpany, że nie zdołał utrzymać wózka na pochyłości gościńca, ociekającego potokami błota. [...] Flis, nie wyzywając wypadku, zeskoczył na ziemię, która zdała się rozstępować pod jego ciężarem, tryskając kaskadą ciężkich, lepkich sopli błota. (HF I, 7-10)

Oczywiste są w nich echa młodopolskiego antyurbanizmu: miasto, od przedmieść po centrum, młodopolanie często charakteryzowali jako potworne, budzące grozę i obrzydzenie monstrum ${ }^{20}$. Mueller, znakomi-

\footnotetext{
${ }^{19}$ Jest to zgodne z planem Drohobycza w I połowie XX wieku. Por. http://www.lvivcenter. org/pl/umd/map/plan-miasta-drohobycza-\%D1\%811925/ [dostęp dn. 04.04.2013]. Zob. o kulturotwórczej roli kolei: W. Tomasik, Ikona nowoczesności. Kolej w literaturze polskiej, Wrocław 2007. J. Sosnowski zwraca uwagę, że opis kolejowej podróży Flisa do Rokomysza zawiera „wszystkie charakterystyczne elementy, współtworzące [negatywną - B.K.O.] semantykę kolejnictwa na przełomie wieków". Zob. tenże, Czas żelaznych potworów, [w:] Szybko i szybciej. Eseje o pośpiechu w kulturze, red. D. Siwicka, M. Bieńczyk, A. Nawarecki, Warszawa 1996, s. 133. Wrażenia z podróży gościńcem prowadzącym od dworca do miasta stają się zatem swoistą kontynuacją traumatycznych przeżyć zapoczątkowanych w wagonie kolejowym.

${ }^{20}$ W. Gutowski, Symbolika urbanistyczna w literaturze Młodej Polski, [w:] Miasto - kultura - literatura. Wiek XIX, red. J. Data, Gdańsk 1993, s. 189-211. Badacz wspomina tam o dwóch typach młodopolskiej wyobraźni antyurbanistycznej: mieście jako przestrzeni stłumienia
} 
cie wykorzystując inspiracje poetyką naturalizmu, podtrzymuje to przeświadczenie. Rokomyski gościniec stanowi karykaturę funkcjonalnej ulicy. Bruk byle jak położony, śliski i niebezpieczny, pełen wybojów i dziur, wypełniony lepkim błotem demonstruje swą dysfunkcyjność, wrogość wobec użytkownika i można byłoby go potraktować jako groteskową wizytówkę miejskich aspiracji Rokomysza oraz niechęci tego miasta do podróżnych. Gościniec w Henryku Flisie ukazany jest jako połączenie żelaznej drogi (kolei) z organizmem miejskim miasta, które de facto stara się blokować kontakty pomiędzy światem i partykularzem. Mueller koncentruje się na sugestywnym opisie błota, bagna, ewokując tym samym skojarzenia z brudem i śmiertelnym niebezpieczeństwem. Co ważne, w opisie tym (na pozór skonstruowanym jedynie wedle antyubranistycznego scenariusza) zostały uwzględnione treści o wartości dokumentalnej:

Błoto Rokomysza (Drohobycza) i Zastawia (Borysławia) było konsekwencją warunków geologicznych terenu, obfitującego w siarczki, solanki, przede wszystkim zaś w naftę i wosk (eksploatowane przemysłowo, a z czasem i leczniczo). Szybkość uprzemysławiania tego okręgu (zwanego wschodniokarpackim zagłębiem galicyjskim) sprawiła, że bardzo żywy ruch komunikacyjny odbywał się na niebrukowanych jeszcze prymitywnych drogach ${ }^{21}$.

Gościniec prowadzi zatem ku miastu, które jest tworem prowizorycznym, konstytuowanym ad hoc (jak stawiane przy nim i zamieszkiwane pospiesznie kamienice). To miasto, podobnie jak prowadząca do niego droga, zostało zaskoczone swoimi nowymi funkcjami. Zresztą tylko podmiejski gościniec nadaje pokracznym chałupom charakter przedmiejskich siedzib, swoiście je nobilitując. Zatem, mimo całej swej szkaradności, spełnia ważną funkcję, zapowiadając metamorfozę przestrzeni niezurbanizowanej w kolejny fragment polis.

W tym miejscu należy też poruszyć ważną dla obrazu ulic w Henryku Flisie kwestię lokomocyjności. Wiadomo, że bohater przybywa do miasta,

i zaniku życia, symbolu śmierci i metafizycznego zatracenia, synonimie entropii i pustki oraz przestrzeni życia chaotycznego, animalnej energii, obszarze wyzwolenia najniższych instynktów, synonimie depersonalizacji i destrukcji ideałów (tamże, s. 190). Zob. też I. Maciejewska, Wielkie miasto w prozie okresu Młodej Polski a problemy naturalizmu, [w:] Problemy literatury polskiej okresu pozytywizmu, seria III, red. E. Jankowski, J. KulczyckaSaloni, Wrocław 1984.

${ }^{21}$ M. Puchalska Przypisy, HF I, 251; A. Chciuk, z perspektywy emigracyjnej wspominając czasy drohobyckie, zapisuje, że „Borysław i Drohobycz pachniały [...] ropą i błotem” (tenże, Atlantyda, s. 132). Inny cytat: „[...] zapuścili się w wąską czeluść uliczki przedmiejskiej, zawaloną błotem, brudem, kupami wstrętnego śniegu. [...] Helena nie zważając na wiatr, nie patrząc pod nogi, brnęła środkiem ulicy, nurzając lśniące kalosze w brudnym, cuchnącym błocie. Flisa imała się zazdrosna złość na ten widok, zniecierpliwienie podlazło mu do gardła" (HF II, 168). 
które liczy 60 tysięcy mieszkańców, ma siedzibę starostwa (HF I, 49). Jednak brak w tekście informacji o tym, by poruszały się po jego ulicach dorożki, karety (lub samochody, które w pierwszej dekadzie XX wieku jako środek transportu stanowiły rzadkość, choć zdarzały sięę) etc. Jedynie Hutowicz, jeden z biurowych znajomych Flisa, wspomina, że niegdyś po mieście „własnymi końmi paradował i fagasa obok siebie sadzał” (HF I, 59). Mieszkańcy Rokomysza wszędzie docierają pieszo. Chodzą na spacery, do pracy. Ulice nie służą im jednak do przejażdżek. To oczywiście potęguje wrażenie prowincjonalności, anachroniczności ich miasta. Tylko drynda na podmiejskim gościńcu oferuje im (jak się wydaje) możliwość skorzystania z kołowego transportu, gdy udają się w stronę dworca lub po podróży wracają do domu (HF II, 234). Ulica jest domeną pieszych, gościniec - poruszających się pojazdem. $Z$ tym wiąże się również sposób percypowania przestrzeni. Jak wiadomo, impresjoniści i „malarze życia nowoczesnego", zainteresowani syntezą różnych form ludzkiej aktywności w środowisku tworzonym siłami człowieka, często przedstawiali ulice widziane $\mathrm{z}$ wyso$\mathrm{ka}^{23}$. Tylko podwyższony punkt widzenia, choćby wysokość miała oznaczać jedynie poziom kozła prymitywnej bryczki, pozwala zobaczyć dalszą perspektywę drogi niż z pozycji pieszego obserwatora i doświadczyć percepcji „przestrzeni w ruchu”. Dlatego wiodąca ku miastu droga obsadzona rachitycznymi drzewami przez swe niezwykłe kadrowanie (rozciągnięcie perspektywy analogiczne do sposobów prezentowania promenad i bulwarów miast zachodnich) nabiera sensu przewrotnego dialogu ze sposobami portretowania miasta, preferowanymi przez artystów nowoczesnych. Spojrzenie ich wiodło ku nieustannemu ruchowi, zmianie, pulsowaniu życia. W Henryku Flisie dokumentuje tylko stagnację i bezwład prowincji na wpół uwięzionej w życiu natury.

\section{Rynek}

Rynek rokomyski tworzył olbrzymi czworobok, wydęty w środku w kopę, opadającą wyboistym brukiem ku bocznym chodnikom, które z tego powodu mokły w kisnącym lepkim błocie. Czworobok zamykały ze wszech stron nierówne rzędy piętrowych kamienic i walących się, roztrzęsionych domków, krzyczących pstrokacizną otynkowania, przygniecionych wysokimi dachami, krytymi sczerniałym i przegniłym gontem lub rdzawą blachą.

${ }^{22}$ W. Budzyński, Miasto Schulza, Warszawa 2005, s. 16. Autor, powołując się na zapis M. Mściwujewskiego (autora wspomnień o życiu w Drohobyczu), podaje, że właścicielem pierwszego samochodu osobowego w Drohobyczu, w roku 1904 lub 1905, był doktor B. Kozłowski, dyrektor miejscowego szpitala.

${ }^{23}$ Jako pierwsi eksperymentowali z takim punktem widzenia miejskiej przestrzeni Manet i Pisarro - zob. D. Kudelska, dz. cyt., s. 298. 
Niskie, progami pod poziom chodnika wtłoczone drzwi wchodowe, czarne jak lochy piwniczne, ziejące cuchnącym brudem i niechlujstwem, przeplatały się na przemian z półkolistymi, niezgrabnymi wjazdami, przeżytkami gościnności staropolskiej i karczemnej polityki komunikacyjnej. Z nędznych żydowskich kramów, przed którymi sterczały obrzydliwe stołki zawalone zachęcającym do kupna towarem, buchał gesty odór stęchlizny, wilgoci, śledzi, zjełczałego masła i nafty. Wonie te, zmieszane z ostrymi wyziewami końskiego moczu, rozmiesionego kopytami z błotem ulicznym w jedno trujące bagno, zawalały powietrze nudnockliwą ciężka, zapierająca oddech atmosferą. Na środkowe wzniesienie rynku wgramolił się niezgrabny, pękaty ratusz, trawiasto zielony, krótki a garbaty, strzelający w jednym rogu nieproporcjonalnie cienką wieżą, rozpadającą się z zaniedbania i podtrzymaną drewnianym prowizorycznym rusztowaniem. (HF I, 22-23)

Gdyby nie świadomość, że ten literacki obraz powstał w pierwszej dekadzie XX wieku, można by pomyśleć, iż mamy do czynienia z którąś z prac Jerzego Dudy-Gracza. Estetykę brzydoty, która tak wyrazista jest w prozie polskiej po 1907 roku (Jaworski, Liciński, Irzykowski, Korczak ${ }^{24}$, znakomicie reprezentuje przywołany powyżej cytat. Centralny plac, z którego wychodzi siatka ulic, jest rozsadnikiem brudu, odoru, bezguścia i przygnębienia. To miejsce jawi się bohaterowi, który ma rozpocząć w Rokomyszu swe dorosłe życie, jako ponura zapowiedź „więzienia”, "zidiocenia", „zezwierzęcenia” (HF I, 23). Najbardziej bodaj w tym obrazie interesujące jest to, że percypowana (ze szczegółami) przez bohatera przestrzeń miejska zupełnie pozbawiona jest ludzi. Są ślady wskazujące na ich istnienie, ale brak jakichkolwiek sylwetek postaci. Ten makabrycznie opustoszały fragment miasta ożywią nieco wałęsające się psy, „osowiałe i zgaszone, z głowami pospuszczanymi w zadumie, z ogonami wetkniętymi smętnie między tylne nogi", "zgnębione do bezczucia” 25 (HF I, 23), choć to ożywienie tylko potęguje wrażenie infernalne. Inferno należy tu rozumieć wedle supozycji Dantego, jako miejsce radykalnego porzucenia nadziei, utraty sensu istnienia i działania. Rynek w Rokomyszu nosi wszelkie znamiona przestrzeni profanum, nie tyle groźnego, co demotywującego, alienującego. Obraz ten lokuje się na antypodach Flisowych wyobrażeń o miastach europejskich, których widok „zachęcał do heroicznych prób i lotów". Bezosobowy marazm, skumulowany w centralnej przestrzeni miasta, jest zarysowany z naturalistyczno-ekspresjonistyczną sugestywnością.

Rynek w Henryku Flisie konsekwentnie prezentowany będzie jako tło wydarzeń związanych z napięciami społecznym: najpierw zbrojną

${ }^{24}$ R. Okulicz-Kozaryn, Gest pięknoducha. Roman Jaworski i jego estetyka brzydoty, Warszawa 2003. Zob. U. Eco, Historia brzydoty, przekład zbior., Poznań 2009.

${ }^{25}$ Narrator zapytuje retorycznie: „,[...] może one były wymierającym pokoleniem filozofów w tym zapadłym kącie?" (HF I, 23). Trzeba docenić bardzo pomysłowe, wielopoziomowe, przy okazji stricte etymologiczne, skojarzenie sytuacji rokomyskich z poglądami filozofów szkoły cynickiej i rozszerzonym znaczeniem cynizmu jako postawy wobec rzeczywistości. 
pacyfikacją tłumu popierającego strajkujących robotników kopalni naftowych (HF II, BB), potem z postojem osób deportowanych za udział w strajku.

Całe wzniesienie pod ratuszem roiło się od osobliwego zbiegowiska. Dziwaczny cygański obóz, tłum żebraków czy włóczęgów. Wszelkiej płci i wieku. Rozsiedli się grupami na podmurowaniu ratusza, na ogromniej studni, na płytach chodników, na tobołkach różnej wielkości i kształtu, pozwijanych w kraciaste, podarte chusty i brudne prześcieradła. Inni znów stali oparci o mur lub latarnie, bez ruchu, jak skamieniali, lub wałęsali się bez celu zmęczonym krokiem, patrząc ponuro pod nogi. [Dalej następuje opis poszczególnych postaci oraz przemocy straganiarza wobec dziewczynki kradnącej z głodu bułkę - B.K.O.] Tuż za nim błyszczał złocony dziób czaka żandarmskiego i najeżone ostrze bagnetu. (HF II, 14-16)

Centralny plac miasta w powieści Muellera zawsze kojarzy się negatywnie. Nie tylko z powodu brzydoty, pustki, grozy. Nie jest miejscem spotkań integrujących miejską społeczność; przeciwnie - raczej podkreśla alienację i wykluczenie. Staje się widownią przemocy i deprecjonującej segregacji. Jest (topograficznie i historycznie) i nie jest (socjalnie i estetycznie) centrum miasta. To kolejny znak problemów Rokomysza z kształtowaniem siebie jako civitas. To miasto o pustym środku, zdewaluowanym centrum ${ }^{26}$. Zła prognoza dla reszty społecznego organizmu.

\section{Aleja akacjowa}

W bezpośredniej bliskości rynku, tuż za kościołem²7, który robił „raczej wrażenie zamku średniowiecznego, niż świątyni” (HF I, 24) i który potrafił „oczarować surowym majestatem [...] tak różnym od kramarskiej pospolitości wszystkich odniesionych [przez Flisa - B.K.O.] wrażeń w tym nowym, odpychającym mieście" (HF I, 25)

[...] przypierała długa, równa aleja ginąca w perspektywie oddalenia. W przeciwstawieniu do śródmieścia, tchnęła ona mieszczańskim, utrwalonym dobrobytem, beztroskim zaciszem zamożnego zakątka. Spoza starannie przystrzyżonych, równymi szpalerami biegnących rzędów akacji [...] ciągnęły się, jedna za drugą, wille, zameczki i pałacyki, lśniące czystością i przesadną nieco świeżością zabawek, wyjętych przed chwilą z pudełka, przeładowane narzucającym się wiedeńskim barokiem tarasów, ganków, wieżyczek, arkad i glorietek. Z osobna brane pod uwagę musiałyby wzbudzić w widzu niesmak swym parweniuszowskim nadęciem i bezstylowością; lecz w miłym, chaotycznym nieładzie ich

${ }^{26}$ O sensie centrum zob. J. Derrida, Struktura, znak i gra w dyskursie nauk humanistycznych, tłum. M. Adamczyk, „Pamiętnik Literacki” 1986, z. 2 , s. 252 i nast.

${ }^{27}$ Chodzi o zabytek wybitnej klasy, gotycki kościół pw. Matki Boskiej i św. Bartłomieja, ufundowany w 1392 roku przez króla Władysława Jagiełłę. Pomyślany również jako budowla obronna. 
ustawienia jakże zacierały się zbyt krzykliwe i wyzywające szczegóły, jak dyskretnie kryły się w cień drzew przydrożnych, ogrodów obwiedzionych sztachetami albo żywopłotem, i jak to słońce zachodzące, jesienne, olbrzymie, krwawe poczynało sobie z nimi pieszczotliwie, z jaką rozbrajającą czułością głaskało i ugłaskiwało kłótnie stylowych sprzeczności, jak gdyby po to właśnie wdarło się w tej chwili w niska, równą wstęgę seledynu, błyszczącą nad miastem, jak mosiężna opaska w krąg mgłami kipiącego kotła...

Ulica była pusta: szeregi akacji zlewały się w głębi w dwa mury zielone, coraz węższe i węższe, prowadzące wprost w słońce. Jeno czekać, kiedy opadną mosty zwodzone i rozewrą się miedziane wierzeje...

I wprost z gościny słonecznej zdawała się iść ku Flisowi jakaś postać niewieścia, majacząca w głębi alei. [...] Więc daremnie rozdzierał powieki tknięte olśniewającym blaskiem: twarz jej rozpływała się we mgle, majaczyła tylko kusząco, bo głowa jej wprost na słonce padała, głowa widmowo mistyczna, [...] ujęta w wąski otok krwawozłotej aureoli. (HF I, 25-26)

Aleja akacjowa to ulica Mickiewicza (HF I, 149) ${ }^{28}$, najparadniejsza ulica miasta (HF I, 27). To po niej, a nie po rynku czy po parku ${ }^{29}$, spacerują wszyscy ważni obywatele. To tu wieczorami „pobłyskiwały cylindry, szeleścił jedwab, włóczyły się wonie perfum” (HF I, 148), tu spacerowicze „odwzajemniali ukłony przechodniów, powolnie, z czołami obarczonymi powagą ciężkich myśli, gawędzili o rzeczach błahych, beztroskich, czynili uwagi o spotykanych znajomościach, wtajemniczali się wzajem w odnoszone wrażenia" (HF I, 149).

Długa, prosta równa droga gwarantowała rokomyszanom komfort przechadzek $^{30}$, który wówczas tak uwielbiali mieszkańcy stołecznych miast. Ulica Mickiewicza, jako jedyna przypominająca wielkomiejski bulwar (HF I, 37), mogła stanowić namiastkę przestrzeni eksploracji dla flâneura ${ }^{31}$, „wyjątkowe-

${ }^{28}$ R.I. Pastuh, Vulicâmi starogo Drogobiča, L'viv 1991, s. 73-90.

${ }^{29}$ Park to w Rokomyszu miejsce zaniedbane, ponure, błotniste. Postawiony w jego bliskości pomnik Mickiewicza jest równie brzydki jak towarzyszące mu otocznie (HF I, 51). Przez park albo przechodzi się pospiesznie, albo stanowi on miejsce schadzek.

${ }^{30}$ Narrator odnotowuje szczegół, że gdy spadł śnieg, posługacze dbali o to, by nie zalegał na trotuarze. „Brzęczały dzwonki sanek. Posługacze miejscy odmiatali śnieg, nagromadzony na chodniku. Tu i ówdzie spoza witraży rozjarzonych, dawały się słyszeć stłumione dźwięki fortepianu" (HF II, 141). W mieście, w którym błoto zalegało na wszystkich ulicach, tu też się pojawia, ale jedynie wtedy, gdy aura jest szczególnie niekorzystna.

${ }^{31} \mathrm{O}$ pojęciu flâneryzmu zob. W. Benjamin, M [Flâneur], [w:] tenże, Pasaże, tłum. I. Kania, Kraków 2006, s. 461-427. E. Paczoska w Prawdziwym końcu XIX wieku: nowoczesności konstatuje: „O zjawisku flâneura napisano już bardzo (może zbyt) wiele - ja chcę [...] podkreślić, że »flanowanie« jest alternatywą wobec podróży. Zwłaszcza - wobec podróży o ustalonych trasach i zaplanowanych poznawczych wydarzeniach" (za: http://www.polona.pl/ Content/40473/ocr.txt [dostęp dn. 04.04.2013]. Por. A. Nowaczewski, Szlifibruki i flâneurzy. Figura ulicy w literaturze polskiej po 1918 roku, Gdańsk 2011; S. Morawski, Trudny zwiazek flânerie z intelektualizmem. Musil, Sartre, Benjamin, [w:] Pojednanie tożsamości z różnica? red. E. Rewers, Poznań 1995.; B. Frydryczak, Okiem przechodnia: ulica jako przestrzeń estetyczna, [w:] Formy estetyzacji przestrzeni publicznej, red. S. Wojciechowski, A. Zeidler-Janiszewska, 
go obserwatora wśród wielu pieszych" ${ }^{32}$. Takie odczucie ma Flis, gdy po raz pierwszy zażywa wieczornego spaceru po Mickiewicza (HF I, 117).

W literackiej biografii Flisa akacjowa aleja odgrywa rolę wyjątkową. Tylko ją może młody prawnik z czystym sercem porównać do drogi we Florencji ${ }^{33}$, co oznacza, że tylko ona spełnia warunki stawiane przez bohatera ulicom par excellence - ulicom prawdziwie europejskim. Ułomności jej eklektycznej architektury zostają zamaskowane przez światło słoneczne, i to $\mathrm{w}$ granicznym jego natężeniu ${ }^{34}$. Właściwym reżyserem pierwszego spotkania Flisa i Heleny jest światło, które w tym przypadku uniemożliwia pełną percepcję wzrokową rzeczywistości ${ }^{35}$. Dlatego właśnie, przez „kaprys światłocienia” (HF I, 27), spotkana wówczas postać może pozostać tajemnicza. Prowokuje to do późniejszego dookreślania jej charakteru przez odniesienia do sztuki: a to „chodzącego cyprysu” z dzieła Böecklina (HF I, 33) ${ }^{36}$, a to do ikonografii wniebowstąpienia (precyzyjniej: ukazania się świetlistej postaci kobiecej na tle nieba $^{37}$, co przywodzi na myśl ikonograficzny typ Assunty), obrazów

Warszawa 1998; N. Forgione, Everyday Life in Motion: The Art of Walking in Late - Nineteenth - Century Paris, „The Art Bulletin” 2006, t. 87, nr 4, s. 664-687.

${ }^{32}$ D. Kudelska, dz. cyt., s. 204.

33 „Przechodzili w milczeniu wzdłuż wysokiego muru, otaczającego plebanię. Przez mur przechylały się długie pręty gałęzi, obarczone mokrym śniegiem. Miejscami tworzyły bramy tryumfalne ponad ich głowami, to znów gięły się tak nisko, że musieli się schylać, by uchronić się przed draśnięciem. Lub odginali je rękami, a wówczas całe błamy puchu roztrząsały się na ich ramionach. Flisowi przypomniała się pewna uliczka we Florencji, wiodąca do Fiesole, wąska uliczka zamknięta dwoma rzędami murów wysokich, szarych, na których kwitły ogrody białych róż. Villa della rosa - przyszło mu na myśl i rzekł: tu różom kwitnać..." (HF II, 136).

${ }^{34} \mathrm{O}$ roli światła w kształtowaniu obrazu plastycznego zob. D. Kudelska, dz. cyt., s. 207.

${ }^{35}$ Wpływ światła na percepcję wzrokową i kształtowanie się wyobrażenia o rzeczywistości szczególnie pasjonował w tym czasie twórców zainteresowanych impresjonizmem i postimpresjonizmem. Zob. rozdz. Luminizm, [w:] W. Juszczak, Malarstwo polskiego modernizmu, Gdańsk 2004, s. 133-228. Zebrane w niniejszym rozdziale głosy polskiej krytyki artystycznej przełomu XIX i XX uświadamiają powszechność tej problematyki i uwrażliwienie artystów pióra i pędzla na jej różnorakie przejawy. O reperkusjach prymatu władzy wzroku w modernizmie zob. M. Jay, Kryzys tradycyjnej władzy wzroku. Od impresjonistów do Bergsona, tłum. J. Przeźmiński, [w:] Odkrywanie modernizmu. Przekłady i komentarze, red. R. Nycz, Kraków 1998.

${ }^{36} \mathrm{O}$ znaczeniu Böcklina dla pokolenia modernistów zob. A. Nowakowski, Arnold Böcklin. Chwała i zapomnienie, Kraków 1994.

${ }^{37}$ „I wyobraź pan sobie, że w taż chwili wielkie zapadające słonce jesienne tkwi płomiennie w wąskiej przepasce seledynu, przeciągniętej przez skłębienia chmur i jakby odpoczywając w drodze na sen, opiera swój promienisty krąg na jej wąskich spadzistych ramionach i głowę jej ujmuje w złoty otok aureoli. Cała aleja rozbłyska tym światłem, rozpływa się w bajkę purpurową" (HF I, 33). 
Giorgonego ${ }^{38}$ etc. Żadne z takich skojarzeń nie byłoby możliwe, gdyby nie odpowiednia rama ujrzanego obrazu, dzięki niej bowiem doszło do kondensacji wrażeń. W Rokomyszu ramę godną takiej epifanii mogła zagwarantować tylko jedna, w sensie klasycznym harmonijna, ulica. I spełniła swoje zadanie. Pozytywne doświadczenie było tak silne, że nawet upadek na tej ulicy, gdy „poślizgnął się [...] na krawędzi chodnika, [a - B.K.O.] zatoczywszy kilkakroć rękami półkole w powietrzu, runął jak długi w rynsztok przydrożny", nie zmusił Flisa do przewartościowania w postrzeganiu uroku „alei akacjowej”. A przecież de facto tam właśnie doznał

splugawienia błotem: błoto ściekało w gęstych wstrętnych soplach z rękawów, palców, a nawet z nosa i posklejanych w kosmyki włosów. Prócz tego biły zeń wyziewy tak niedwuznacznego pochodzenia, że ogarniała go dławiąca nuda obrzydzenia, a dech zamierał mu w piersi (HF 1, 27).

Dzięki temu upadkowi jego losy splotły się z dziejami Ostrowskiego - radykalnego socjalisty, jednego z głównych ideowych adwersarzy bohatera. Jego mieszkanie znajdowało się w kamienicy przy Mickiewicza. Tam nawet błoto okazuje się funkcjonalne, a upadek do rynsztoka inicjuje ważne biograficzne wątki.

\section{Ulica zamiejska}

Zostawili już miasto za sobą i wkroczyli w jakąś dróżkę przedmiejską, zamkniętą z lewej strony szeregiem białych domków, po prawej zgoła nie zabudowaną. Droga wiła się po wzniesieniu: urywała się prawą krawędzią w głęboki jar, u którego dna rozkisała ziemia $\mathrm{w}$ ciemne torfowisko pełne przegniłych, $\mathrm{w}$ konwulsjach zamierania poskręcanych badyli. Poza trzęsawiskiem, w którego końcowych odnogach grzęzły pierwsze, przyziemne chałupy, wznosił się teren połogo w górę i odcinał się wyciągniętą, horyzontalną linią obsadzoną smukłymi, odwiecznymi topolami i ostrymi kupami szutru wzdłuż rządowego gościńca. A dalej, jak okiem sięgnąć, rozległa dolina, obramiona u widnokręgu stokami sinych przedgórzy i gór, które występowały jedne za drugimi jak kulisy, coraz wyższe, bledsze i niewyraźniej zaznaczone, zwełnione u falistych krawędzi barankiem zalesień, póki się nie rozpłynęły w jasnym, mlecznosinym niebie. Nad wszystkim wisiała śreżoga dymów białych i srebrnych, przerżnięta tu i ówdzie spokojnymi, prostopadłymi liniami czarnego kopcia fabrycznych kominów [...]. Kędyś w dali wyzierała przez zasłonę mgły mała, czarna cerkiewka, z czterema gontowymi kopułami i złotym, migotliwym krzyżykiem, pozbawiona wszelkiej bryłowatości, jakby wycięta z kartonu.

\footnotetext{
${ }^{38}$ Relacje powieści S.A. Muellera (i szerzej: twórczości lwowskich młodopolan) z twórczością Giorgionego to osobny, obszerny wątek, wart rozwinięcia w oddzielne studium. Tu jedynie należy go zasygnalizować.
} 
[...] Te białe dymy, poza fabrycznym czadem? Tam, ot, aż u stoków gór? Tam ten raj, tam ta ziemia obiecana. (HF I, 60-61)

Ulica, przy której znajduje się dom Hutowicza, kontrastuje z aleją akacjową (Mickiewicza). Aleja jest ulica, dla której proces formowania już się zakończył. Znajduje się w centrum miasta i przemierzający ją przechodzień ma ściśle określone możliwości percypowania przestrzeni, wyznaczone przede wszystkim topografią i układem elementów architektonicznych i zieleni miejskiej (szpalerów drzew). Ulica przedmiejska jest niedokończona, jakby miasto na niej właśnie się urywało. Jej specyficzne położenie (zawieszenie nad uskokiem) czyni z niej rodzaj widokowego tarasu. To też rodzaj obserwatorium, ale o zupełnie innym charakterze niż śródmiejskie drogi. Wzrok nie koncentruje się tu na współuczestniku miejskiej przestrzeni. Ulica przedmiejska pozwala, pozostając w mieście, widzieć odległa perspektywę, w której sąsiadują ze sobą komponenty natury (roślinność, góry), ludzkiej działalności przemysłowej (szyby naftowe) i akcenty przypominające o wartościach duchowych (cerkiewka). Jest miejscem, w którym z jednej strony dokonuje się synteza różnych wymiarów ludzkiego bytowania, z drugiej zaś idylliczny pejzaż karpacki naznaczony deformująca go przemysłową prymitywną „, architekturą" tu właśnie przekonuje o nieuchronności metamorfozy cywilizacyjnej. Co ciekawe, miejsce to w równej mierze budzi estetyczny podziw, jak i skojarzenie z Ziemią Obiecaną ${ }^{39}$, w epoce Młodej Polski często eksponowane. Oczywiście bliżej jej do Reymontowskiego wzorca niż do archetypu znanego z ksiąg biblijnych.

Nienazwana ulica przedmiejska dla Flisa będzie przez czas jego pobytu w Rokomyszu miejscem o szczególnym znaczeniu. Najpierw w domu Hutowiczów ulokuje się jako lokator, potem będzie go regularnie odwiedzał, trudniąc się śledzeniem ukochanej Heleny. Na tej ulicy doświadczy spotkania z dziewką uliczną:

Tuż przed swym mieszkaniem zauważył Flis dziewczynę. Minął ją i przystanął pod latarnią. Była młoda i świeża. Przemówił - i poszli razem. Było wietrzno i mżyć zaczął drobny, przykry deszcz. [...] nagle Flis zawrócił w miejscu i oddalił się spiesznie, jakby go kto gonił. Bo kiedy dziewczyna uniosła sukni, przechodząc przez błotnistą ulicę, spostrzegł, że ma powykrzywiane trzewiki i podartą pończochę. Długo się jeszcze wałęsał po mieście. (HF I, 115)

Strój prowincjonalnej prostytutki z przedmieścia budzi we Flisie estetyczny dyskomfort. Ten sam odruch nie pozwala mu z aprobatą wypowiadać się o ulicy przedmiejskiej. Zauważa jej walory jako przestrzeni

\footnotetext{
${ }^{39} \mathrm{~W}$ powieści Hutowicz, widząc dolinę na tle gór, recytuje nawet fragment Księgi Powtórzonego Prawa (Pwp 32, 48; 50-52) - HF I, 61-62.
} 
ciekawej, oswojonej, pociągającej. Jednocześnie jej niedomknięcie, niedokończenie, zaburzenie równowagi pomiędzy częściami składowymi (domy, droga, krajobraz) powoduje, że nie może jej zamknąć w kadrze, którego prototyp przywiózł ze sobą wraz z bezcenną walizką.

\section{Ulice historyczne i widmowe}

W sieci rokomyskich ulic można pobłądzić, zwłaszcza nocą ${ }^{40} \mathrm{i}$ gdy nadmierna ilość trunku utrudnia orientację:

Musiała już być późna godzina, bo latarnie właśnie gaszono. Na ulicach panował mglisty mrok, tu i ówdzie tylko migotały światła spoza żaluzji okiennych. Szedł niepewnie, potykając się co chwila, zatrzymywał się pod latarniami, na rogach ulic, orientował się, błądził. Na nieznanej, odludnej uliczce natknął się na spieszącego się mężczyznę. Ukłonił się nisko, poprosił o wskazanie drogi. Właśnie przyjechałem - mówił - nie znam miasta. (HF II, 145)

Pechowo napotkanym rozmówcą okazał się Ostrowski, więc fingowanie Rokomysza jako struktury labiryntowej szybko wyszło na jaw.

Prawdziwe „miasto niewidzialne”, miasto w mieście, pokazała Flisowi dopiero Helena, która niczym Beatrycze oprowadzała go po swoim raju - miejscach świadczących o dumnej przeszłości grodu:

[...] oprowadzała go po brudnych, cuchnących zaułkach żydowskich, po ciasnych uliczkach, które służyły za zlewy nieczystości licznym żebraczym rodzinom, tłoczącym się w izbach niskich, kurnych, ciemnych. Wskazywała, którędy szły dawne wały miejskie, zwracała uwagę na okaleczałe ich szczątki, na rozkopane wzgórki, przemienione w śmietniska, na fosy zanieczyszczone odpływami kanałów, co zamarzały w mętne skorupy lodowe, wśród zbrukanego ohydnie śniegu. Odbudowywała z gryzów drewniane baszty... [...] Pod wpływem tych opowieści ulegały oczy Flisa ewangelicznej ślepocie wobec nędzy i niedoli, tym kątom zapadłym przytomnej, dusza jego oczyszczała się z wszelkiej goryczy, która truła się dotychczas na widok upośledzenia wydziedziczonych, wszystko stawało się w krótkich błyskach wyobraźni zrozumiałym, pełnym znaczenia i racji wyniosłej z dziejowych rozmyślań. (HF II, 164-165)

\section{Wizję ulic swojego miasta Helena przedstawia w wyznaniu:}

[...] jestem mieszczańską córką. [...] Glebae adscripta - duszą. [...] czy mi pan uwierzy, że nieraz, kiedy przechodzę tymi zaułkami, wyrasta przed mymi oczyma wprost namacalna wizja tego prastarego grodu, jakby się życie cofnęło o pięć wieków? Chodzę, jak we śnie,

\footnotetext{
${ }^{40}$ Henryk Flis często przemierza ulice Rokomysza po zapadnięciu zmroku. Nawiązania do obrazów ukazujących sceny nocne (nokturnów), popularnych w sztuce XIX wieku, zaobserwować można w dziele Muellera wielokrotnie zob. HF I, 126-127, 145, 216; II 38, 52, 119, 141, 201, 209.
} 
i dotykam przedmiotów, co dawno w proch się rozsypały. Spotykam oblicza, które już chyba tylko stare płótna zachowały potomnym. Słyszę ich głos, rozmawiam z nimi. Kiedy sobie nagle uświadomię złudę tej cudnej fantasmagorii, ogarnia mnie trwoga, że umysł mój grąży się w mrokach manii. Lecz wkrótce żałuję, że mi wróciła nieproszona trzeźwość. (HF II, 165)

Cudna fantasmagoria Heleny pozwala widzieć i czytać ulice, zaułki miasta jak drogocenny palimpsest. W widzialną tkankę miejskiej przestrzeni wprowadza swój własny ład, odkrywa jej intrygującą strukturę. Pozwala również na uwolnienie wzroku od balastu powierzchownego wartościowania (zamkniętego $\mathrm{w}$ ramach pojmowania zdroworozsądkowego). Oczywiście fantasmagoria, która dzięki Helenie staje się także udziałem Flisa, wyrasta na podglebiu wiedzy o miejskich realiach. Piękna żona Hutowicza przekonuje swego towarzysza, że zdobyła ja, studiując dokumenty w grodzkich archiwach. W istocie pewnie źródłem informacji była świeżo wydana monografia miasta (HF II, 168) ${ }^{41}$. Odkrywane wspólnie ulice Rokomysza stają się elementem miłosnej gry, uwodzenia i odkrywania siebie w silnie angażującej obydwoje relacji. Kobieta wciela się w rolę romantycznego cicerone, mężczyzna ulega w pełni jej władzy. Ulega między innymi dlatego, że ona ma (poprzez wiedzę) władzę nad miastem.

W planie postrzegania ulic, zaułków i bruków fantasmagoryczne projekcje Heleny i Flisa stanowią bardzo interesujący fragment. Dzięki połączeniu czynnika czasowego i przestrzennego kadry miasta nakładają się, multiplikuja, miejscami przezierają spod siebie, miejscami pozostają nietransparentne. Wyraźnie widać, że obrazy miasta nieistniejącego konstruowane są przy pomocy techniki kolażu ${ }^{42}$.

\section{Obserwatorium}

Ulica w prozie Muellera jest miejscem nieustannej obserwacji. Prowokują uwagę przechodniów ludzie spacerujący po głównej miejskiej arterii (potwierdzają tym samym swe istnienie i społeczną pozycję), bądź tej uwagi odmawiają komuś, kto dla nich jest persona non grata („,unieważnienia" swej postaci doświadczył Flis jako początkujący prawnik - HF I, 117). Z opiniami ludzi spotkanych na ulicy (wyrażanych gestem, mimika, słowem) liczy się Helena Hutowiczowa, spacerująca z adorującym ją Henrykiem. Początkowo takich reakcji się obawia, wszakże w miarę rozwoju

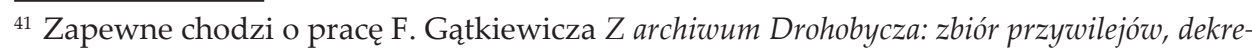
tów organicznych, lustracyj, memoryałów, i.t.p, Drohobycz 1906.

${ }^{42}$ Więcej na temat kolażu i jego filiacji z literatur zob. R. Nycz, O kolażu tekstowym. Zarys dziejów pojęcia, [w:] tenże, Tekstowy świat. Poststrukturalizm a wiedza o literaturze, Warszawa 1995, s. 189-224. Tam obfita literatura przedmiotu. 
ich związku przestaje się z obserwatorami liczyć, a nawet zaciekawienia sobą i towarzyszem oczekuje (HF II, 161). Ulica dla postaci rozpoznawalnych w ulicznym tłumie, takich jak Hutowiczowa czy Flis, z konieczności musi być miejscem spotkań, gdyż wspólne wychodzenie (na przykład do kawiarni czy do mieszkań któregokolwiek z nich) naraziłoby obydwoje na społeczne szykany. Na ulicy Flis nie spotyka się z Mania, uwodzoną szwaczką. Obrona własnej reputacji każe mężczyznom na pracownice wychodzące z zakładu modniarskiego czatować w alejach pobliskiego parku i natychmiast kryć się z nimi po stancjach, pokojach etc.

Z okien domów rokomyskich nieustannie prowadzona jest uważna obserwacja świata, koncentrująca się na przejawach życia publicznego. Rokomysz wprawdzie nie jest ilustracją panoptikonu opisanego przez Michela Foucaulta, gdyż motywacją wzmożonej obserwacji bohaterów nie zawsze jest chęć sprawowania kontroli nad światem. Czasem powody bywają bardziej prozaiczne: próżniactwo i nuda „klasy średniej”"43, której Rokomysz daje niewiele rozrywek, powoduje, że świadkiem upadku Flisa staje wpatrująca się w okno Wanda, wprost umierająca $z$ bezczynności. Flis najpierw z Ostrowskim, potem samotnie, obserwuje z ulicy sceny życia małżeńskiego państwa Hutowiczów. Brak wzmianek o teatralnym życiu rokomyszan pozwala domniemywać, że ulica może stanowić w tym mieście erzac zarówno sceny, jak i widowni nieistniejącego teatru. Ulica oferuje prerogatywy widowni wówczas, gdy umożliwia zaglądanie do cudzych domów lub przez wielkie szyby do najpopularniejszej kawiarni (Baku). Obserwacje bywaja przypadkowe (takie poczyniła Wanda) lub systematyczne, wedle scenariusza fobii miłosnej (Flis). Dla młodego prawnika wgląd w wieczorne życie domu Hutowiczów nabrał wszelkich cech rytuału, kultywowanego z precyzją i świetnie zaplanowanego. Ukrycie w zakamarku ulicy w określonym czasie (późnym wieczorem) jakby niwelowało przestrzeń dzielącą intruza od salonu mieszczańskiej rodziny, pozwalało trwać $\mathrm{w}$ cierpieniu miłosnym.

Ulica osłania swój protosceniczny charakter także w czasie wydarzeń związanych ze społecznymi uroczystościami (pochód ku czci Sienkiewicza) czy niepokojami na tle strajku. Oba te wydarzenia wzbogacają repertuar ról ulicznych o nowe warianty, związane z wieloznaczną semantyką wyróżniającego stroju (raz historycznego kostiumu, raz wojskowego munduru).

Po ulicach rozlegał się miarowy marsz, odgłosy trąbek i bębnów, lakoniczne rozkazy. Migały patrole, zmieniały się warty; wszystkie dzieci wyległy na miasto i gapiły się.

43 Badacze historii Drohobycza zwracają uwagę na fakt, odnotowany nb. w Henryku Flisie, że właściciele firm zajmujących się wydobyciem nafty, wosku oraz inwestorzy na roponośnych terenach Galicji w zdecydowanej większości mieszkali w Drohobyczu, a nie w Borysławiu czy innych okolicznych miejscowościach. 
Pobrzękiwały szabelki o chodniki, dzieciom dusze skakały z radości, kobietom oczy zachodziły łzami i rumieniły się świeże policzki. Szkoda, że nie maj. [...]

Robotnicy przechadzali się grupkami po ulicach, odświętnie przybrani, głodni. Uchylali przed sobą wzajem kapeluszy i mówili: Szczęść Boże. Przezierali się barwnym mundurom wojska z nieufną ciekawością: wielu z nich rzuciło niedawno mundury, wielu odbywało ongiś tak samo patrole i marsze na domowych wrogów porządku, wielu miało może niejeden celny strzał na sumieniu. Czyliżby strój tak przeistaczał duszę? Może strach? Może otoczenie? Kierowali z zimną krwią stal w bratnie serce, które teraz tak im rozdziera się i krwawi, dotknięte zimną stalą brata... Wieczysty krąg życia. Żołnierze tak byli im przychylni, gawędzili z nimi ukradkiem, świadczyli grzeczności ich żonom i córkom... Wojsko deptało ich jak plugawe robaki. Żołnierze a wojsko... Areszta rokomyskie zapełniały się więźniami. (HF I, 220; podkr. S.A.M.)

\section{Świętowanie}

I znów długi cytat, ale trudno go streścić czy omówić. Nie tylko z tego powodu, że to jeden z całą pewnością z najpiękniejszych opisów ulicy w prozie młodopolskiej. Także dlatego, że plastyczno-muzyczna faktura tego opisu nie poddaje się żadnym redukcjom:

Ależ tu życie gra! Co za przedziwna biesiada dla oka! Jakże wdzięczna na każdym kroku przynęta dla malarskiego ukochania barwy, światła, ruchu - dla upodobania estetycznego w harmonii, w rzeczach rzadkich, przekraczających granice szarej codzienności! [...] A było tu wszystko jak w bajce, jak w romantycznym ogrodzie fantazji, jak we wspomnieniu, wyidealizowanym tęsknotami...

Było tu niskie mleczne niebo, niby kapliczny strop, rżnięty z litego opalu, i słońce nad nim ogromne, rażące, białe, jak tarcza kuta z cyny w srebrzystym otoku. I była ulica długa, powietrzna i czysta, pławiąca się w blaskach, pogodna, jak wspomnienia z dzieciństwa. Dwa równe rzędy domów, kamienic, will, pałacyków, rozmaitych białością tynku, czerwienią surowej cegły, lśniącym szkliwem ozdób kaflowych - ujmowały koryto wezbrane powodzią światła. Płynne, niespokojne, mżące, burzyło się ono w zamkniętej przestrzeni promienną falą ulicznego pyłu, przetopionego w lotny metal, przelewało się na boki i tysiącem lśnień, błysków, tonów i półcieni odbite od jednego brzegu, uderzało ławą w brzeg przeciwległy, i tak dalej, wciąż dalej toczyło się, chwiało, pryskało snopami iskier, pękami promieni, bukietami barw w długie rzędy szyb okiennych, w okucia metalowe, w rynny, w blachy domów. Szybom szyby, blachy blachom podawały te balony lotne i świetne rakiety, odrzucając je sobie wzajem, niby obręcze owinięte barwnym papierem. A światło mknęło szerokim korytem ulicy, jak lotny opar, aż hen, kędy jej wylot zamykały strzeliste zarysy kościoła - zamczyska, i tam się wreszcie skraplało na jego dachach, flankach i wieżyczkach, i jak miedź roztopiona sączyło się ciężko w chłód witrażowych półmroków. A domy, wille, i pałace stały w tej ulewie jesiennego blasku, co za oczy chwyta, choć nie grzeje, ciche i uroczyste, zdobne $\mathrm{w}$ festony zielonej choiny, w draperie różnokolorowe, w symboliczne transparenty i wywieszki, pstre makaty i dywany, choragiewki papierowe i płócienne - i w barwne plamy strojów i kapeluszy kobiecych, co wychylały się z otwartych okien ku światłu, jak kwiaty z doniczek, kiedy po raz pierwszy rygle się odemkną i świeże powietrze wiosenne zawionie. A balkony były wesołe, roześmiane, głośne, jedwab tam lśnił 
i szeleścił, wymyślne wonie perfum przeróżnych stamtąd biły i mieszały się z żywicznym zapachem choiny, przesiąkniętym wspomnieniem lasów.

W cały ten hejnał światła, blasków i promieni wciskały się wąskie, długie wstęgi chorągwiane, barwne, pstre, świecące nowością, sztywne, sięgające od okien strychowych prawie aż do ziemi. Wsuwały się lekko, płasko między gałęzie drzew przydrożnych, w sztachety parkanów, kłoniły się statecznie ku sobie, wiązały w akordy kolorowe, jak pęki krasnych krajek wplecione we włosy druhny. Chwilowo stały ciche, nieruchome, jak kulisy czarodziejskiej sztuki w dziecięcym teatrzyku; to znów za najlżejszym powiewem wiatru chwiały się miarowo, poważnie, wznosiły się w górę w wężowych, falistych skrętach, łopotały, jak skrzydła olbrzymich ptaków w odlocie; mieniły się, gmatwały, plątały się o druty telefoniczne, szamotały w uwięzi, jak ryby złotołuskie w sieci, wydymały się na kształt żagli napowietrznej flotylli, gnanej pomyślnym wiatrem $w$ krainy marzeń. Lecz oto wiatr się natęża, złoty pył wirem wznosi się z ulicy, złote liście, jak motyli rój, uderzają w niebo, a chorągwie wstępują ciężko, płasko, sztywne aż ku gzemsom domów i stają chwilę cicho, nieruchomo, w poziomie, i nad całą ulicą wykwita świetna, barwna tęcza. Niebo już ginie, rozpływa się pod tą zasłoną tęczowa, i domy, drzewa, ludzie przeistaczają się w nierzeczywisty, wymarzony ogród baśni, w którym niebo utkane z srebrnolicej gazy, trawniki z kobierców jedwabnych, kwiaty rżnięte z opali, szafirów i szmaragdów, wilgotne rosą diamentów, wonne oszałamiającym zapachem perfum, a ludzie lotni jak mgły, niecieleśni jak duchy, chwytający jak jaskółki w locie miałki żer zachwytu.

A pod tym królewskim przepychem wiszących ogrodów mrowił się tłum. Przelewał się leniwo jak wezbrana rzeka, rozchwiany, płynny, zmienny, mrukliwy. Miejscami wyciągał się jak wąż, pełzający w słońcu skrętami śruby, dzielił się jak odnogi wodne, znów się łączył, pęczniał w zbite zwarte strzępy, zamykające niedostępnym wałem całą szerokość ulicy. Krzykliwi, zziajani członkowie straży obywatelskiej miotali się wśród niego jak świetne karasie, lśniąc nasuniętymi w tył głowy cylindrami, rozrzucając $w$ wietrze długie szarfy honorowych odznak. Wynurzali się nagle tu i tam na powierzchnię, wywijali rękami, krzyczeli ochrypłym głosem, prosili, rozpychali nieposłuszny natłok, ciskali się weń na oślep, jak nurki. Lecz daremnie wytężali wszystkie siły, by utrzymać wolny przejazd ulicą: ledwo się im udało zrobić szczupły wyłom w zbitej masie, a już nowy napór fali go zalewał, porywając ich wraz z nowym prądem. A tłum się przelewał, szumiał, mienił, wzdymał, wyrzucał nadmiar masy na podmurowania sztachet, na tarasy will, na ławki uliczne i drzewa, łłoczył się, niecierpliwił, gorączkował. Chwilami nastawała wśród tłumu cisza tak głęboka, że słychać było przyspieszone oddechy, chrzęst żwiru, szelest suchych liści i gałęzi. Idą już... wołał ktoś, a westchnienie ulgi mknie przez natłok, jak niesione echo morskiego poszumu. Idą już... szyje się wyciągają zwracają się głowy w jednym kierunku, jak na komendę, dłonie podnoszą się do oczu. Chwila niezmąconej ciszy... Złowrogi pomruk zawodu napełnia ulicę, słychać krewkie okrzyki zniecierpliwienia.

A tłum rośnie, burzy się, miota. A słońce go maluje w przedziwne zestroje barw, ciska weń nagłe snopy świateł, wywabia barwne płomyki, zamglewa je, to znów wydziera z chaosu krzykiem blasków, miesza, stapia, wikła, rozprowadza w harmonijne wzory, figury, desenie. (HF II, 6-8)

Ten misternie skonstruowany, dopracowany w szczegółach opis ulicy odświętnej jest wzorowo odrobioną lekcją tworzenia modernistycznych synestezyjnych melanży. Jest też jednym z nielicznych w prozie młodopolskiej zapisów odnoszących się do celebrowania wspólnego miejskiego 
święta, do potrzeby wspólnego ulicznego spotkania w celu świętowania. Thomas Merton twierdził:

Kiedy ulica jest jak tunel, jak kanał, który prowadzi z jednego miejsca do drugiego, ludzie, którzy tam „żyją", tak naprawdę tam nie mieszkają. Jeśli ulica nie jest zamieszkana, staje się wysypiskiem. Ulica nie jest miejscem, gdzie żyją ale miejscem, gdzie zostali porzuceni, jak śmiecie. Jeśli ulica nie jest zamieszkana, staje się wysypiskiem. Ulica może być wysypiskiem dla tysięcy ludzi, których naprawdę tam nie $\mathrm{ma}^{44}$.

Dodawał, że ulica może stać się zamieszkałą przestrzenią tylko wtedy, kiedy stanie się miejscem świętowania ${ }^{45}$. Festyn ku czci Sienkiewicza stał się dla rokomyszan okazją do tłumnego zebrania, wyzwolił społeczną energię (manifestującą się w dekoracjach domów, odświętnych strojach), rozgrzał emocje. Flis dał się unieść fali euforii, mimo wcześniejszych oporów przed stadnym celebrowaniem maskarad, inspirowanych zresztą odgórnie, przez miejscowe władze.

W cytowanym opisie zwraca uwagę wielość perspektyw, w których widziana jest świętująca ulica. Migawkowe ujęcia przestrzeni (widzianej z dołu, z góry, od środka, z daleka, z bliska) tworzą kalejdoskopowe układy. To cięcie i składanie przestrzeni, rzec można: jej montowanie, ma w sobie coś z zapowiedzi praktyk futurystów. Można zadać pytanie, jaki cel przyświeca takiemu widzeniu udekorowanej scenerii ulicznej. Narrator dokłada starań, by „miałki żer zachwytu” stał się atrakcyjny dla odbiorcy. Potrzebuje wyrazistej kreacji światła, tłumu, ruchu obejmującego różne poziomy ulicy, by zestawić ją w szokującym kontraście z apatia, marazmem, biedą masy nędzarzy-„,łamistrajków” zgrupowanych na rynku przed deportowaniem z miasta ${ }^{46}$. Wystylizowana uroda zderzona ze spotęgowaną brzydotą oznacza spotkanie z poetyką ekspresjonizmu i niewątpliwie pierwsza część dyptyku („ulica świętująca”) tworzona jest z myślą o sugestywnej dysharmonii, w pełni uchwytnej dopiero po dopełnieniu obrazu naturalistyczną partią jego drugiej części („obóz na rynku”) .

Flis fałszywie interpretuje zwodniczo piękny maskaradowy charakter integracyjnego spotkania na „paradnej ulicy miasta”, które jest jednak tylko czczeniem powierzchownie pojmowanych istotnych wartości wspólnototwórczych, takich jak tradycja, pamięć, tożsamość etniczna etc. Ostatecznie niebezpiecznie przypomina ono nalepki na podróżnej walizce. Dostrzega też swą bezradność wobec skrzętnego separowania „ludzi zbędnych", powstających z generowanego przez niesprawiedliwość społeczną

\footnotetext{
${ }^{44}$ T. Merton, Ulica jest miejscem świętowania, tłum. W. Grzybowski, [w:] Miasto. Przestrzeń, topos, człowiek, s. 295.

${ }^{45}$ Tamże, s. 300.

${ }^{46}$ Skojarzenie z sygnalizowanym przez Mertona wysypiskiem śmieci jest nieuniknione.
} 
przemysłowego błota, i fałsz rodzącego się wobec nich biernego współczucia. Jego rozdarcie jest symptomatyczne dla wszystkich czujnych obserwatorów życia społecznego w XX ( i XXI) wieku.

\section{Ulica stracona i odzyskana}

Mijał ulice wolno, krok za krokiem, patrzył na wszystko uważnie, notował pilnie w pamięci szczegóły, przystawał, zadzierał głowę, ręce zakładał w tył. Potakiwał, odchodził od ustrojonych domów i znów wracał, wabiony przypomnieniem lada pominiętej drobnostki. Taki rad był wszystkiemu, że tylko rozglądał się dokoła, komu by na szyję się rzucić i wyściskać $\mathrm{z}$ radości. Zachodził w uliczki i uśmiechał się dobrodusznie na widok naiwnych zabazgranych transparentów, koszlawych bombastycznych napisów, postrzępionych szmat kolorowych, powywieszanych z małych oficyn na drągach od szczotek. Rozczulał go ten biedny, nieporadny pietyzm i myślał: oto chwalą Boga, jak mogą. Więc takim jest Sienkiewicz żyjący w duszy narodu? Niechże mu za to będzie część... I cześć narodowi, co sobie dzieło przezeń mu podane ukształtował wedle swej wnętrznej potrzeby... (HF II, 13)

O ironicznym dialogu Muellera z recepcją wpływu Sienkiewicza na kulturę współczesnej mu Polski można napisać studium. Nie to jednak jest przedmiotem niniejszego szkicu, ale obraz ulicy. Flis, o czym już była mowa, przywiózł do Rokomysza pewien zespół klisz ${ }^{47}$, ugruntowujących jego pragnienie związku z urbanistyką klasyczną lub klasycyzującą. Zacytowany powyżej opis ulicy jest tekstem bardzo sugestywnym pod względem siły rozrachunkowej z zaściankowością, z banalnością rachitycznej „artystycznej” wyobraźni kształtującej wartość obrazową rokomyskiej ulicy, demaskującym cywilizacyjną przepaść pomiędzy Europą i aspirującym do jej miana fragmentem prowincjonalnej Galicji. Czy to dla ulicy Rokomysza sygnał nieodwołalnej ekskomuniki ze świata kultury?

Otóż nie. Pod względem technik artystycznych rokomyszanie Muellera, przekształcając tak swoją ulicę, jak zostało to ukazane, wyprzedzili swoją epokę o co najmniej półwiecze (co, biorąc pod uwagę tempo przemian w sztuce najnowszej, oznacza: o lata świetlne). Ich trywialne "dragi od szczotek", ,kolorowe szmaty" i „koszlawe napisy" znakomicie zilustrować mogą jedną z technik postmodernistycznych [sic!], jaką jest bricolaż ${ }^{48}$. Jak wiadomo, jest to technika analogiczna do majsterkowania,

${ }^{47}$ Klisze postrzegania przestrzeni galicyjskich nie były tylko prywatnym pomysłem Muellera. „Brody [R. Jaworskiego - B.K.O.] - podobnie jak Drohobycz Stanisława Antoniego Muellera czy Brunona Schulza - dawały melancholijne poczucie ścisłego związku z rozległymi obszarami Europy, nie dając wielkich nadziei na ich pełne poznanie". Zob. R. Okulicz-Kozaryn, dz. cyt. s. 65.

${ }^{48}$ Zob. inspirujące sugestie dotyczące problemu kultury postmodernistycznej: T. Miączka, Kultura w stylu KISS. Pierwsze, czyli proste - „Keep it simple, stupid?”, www.anthropos. 
w której „„dzieło jest konstruowane z rozmaitych dostępnych materiałów”, najlepiej takich, które mają walor autentyczności i są pod ręką. Bricolage jako projekt tworzenia i interpretowania rzeczywistości fascynował Claude'a Lévi--Straussa ${ }^{49}$, potem Jacques'a Derridę ${ }^{50}$, potem Gilles'a Deleuze'a ${ }^{51}$. To ważne nazwiska współczesnej humanistyki.

Z tej perspektywy trudno nie podzielać wewnętrznej radości Henryka Flisa na widok rodzimych jaskółek bricolage'u. Rokomysz - miasto anachroniczne z powodu swych nieporadnych tęsknot do kultury klasycznej i kulturowo awangardowe dzięki swej tandecie - naprawdę nie ma się czego wstydzić.

us.edu.pl/anthropos6/texty/miczka_2.htm [dostęp dn. 04.04.2013].

49 „Bricoleur zdaniem Lévi-Straussa [zob. Lévi-Strauss, Myśl nieoswojona, tłum. A. Zajączkowski, Warszawa 1969 - uzup. B.K.O.] to ktoś, kto korzysta ze »środków znajdujących się pod ręką", tzn. tych, które znajduje w pobliżu do dyspozycji, które tam już są i nie były specjalnie wymyślone ze względu na operację, do której mają zostać użyte i do której stara się je przystosować na drodze prób i błędów, nie wahając się ich zmienić, kiedy tylko okazuje się to konieczne, czy też spróbować kilka naraz, nawet jeśli ich forma i pochodzenie są heterogeniczne, itd." - J. Derrida, dz. cyt., s. 258. C. Lévi-Strauss używał nazwy bricolage do opisu charakterystycznych stylów myślenia magicznego. Kontekst myślenia magicznego w powieści Muellera warto uwzględnić przy oglądzie posługiwania się z „wmówionymi" mitami Sienkiewiczowskimi.

${ }^{50} \mathrm{~W}$ przekonaniu Derridy bardziej rozwiniętą formą bricolage' $u$ jest „,wolna gra”, czyli przetwarzanie historii symboli, metafor, metonimii i innych znaków w osobliwy, na ogół bezstylowy kolaż rodzajowy i gatunkowy, a nawet w swoisty cytat cytatów. Zob. J. Derrida, dz. cyt., s. 266.

${ }^{51}$ G. Deleuze, F. Guattari, Anti-Oedipus, Capitalism and Schizophrenia, trans. R. Hurley, M. Seem, H.R. Lane, London 2004. 